\title{
Kavramsal metafor kuramı ve belagat: karşılaştırmalı bir inceleme
}

\section{Ahmet Naim ÇİÇEKLER'}

\section{Timur AYDIN ${ }^{2}$}

\begin{abstract}
APA: Çiçekler, A. N.; Aydın, T. (2019). Kavramsal metafor kuramı ve belagat: karşılaştırmalı bir inceleme. RumeliDE Dil ve Edebiyat Araştırmalar Dergisi, (16), 14-26. DOI: 10.29000/rumelide.616880
\end{abstract}

\section{$\ddot{\mathbf{O} z}$}

Bu çalışmada, Lakoff ve Johnson'ın 1980 yılında yayımlanan Metaphors We Live by adlı eseriyle ilk kez literatürde ifadesini bulan Kavramsal Metafor Kuramı'nın kaynak alan, hedef alan, metaforik dilsel ifade, haritalama, yapısal metafor, ontolojik metafor, yönelim metaforları, motivasyon, bedensel gerçekçilik, algıya dayah yapısal benzerlik, deneyimde korelasyon, ana sahne gibi temel kavramları açıklanmakta, belagat geleneğinde metaforun mukabili olan istiare hakkında söylenenlerle çağdaş metafor kuramının ilkeleri mukayese edilmektedir. Ahmed Hamdi Şirvanî (Orak 2013), Ahmed Cevdet Paşa (1323), Recaizade Mahmud Ekrem (1299), Tahir Olgun (1936), Walter Andrews (1976), Yekta Saraç (2015) kaleme aldıkları belagat kitaplarında ve Doğan Aksan (1978) anlambilimle ilgili kitabında metaforu a) dille ilgili bir mesele olduğu, b) retorik bir araç olduğu, c) benzerliğe dayandığı konusunda genel bir uzlaşı hâlindedirler. Halbuki Kavramsal Metafor Kuramı'na göre metafor; a) düşünceyle ilgili bir meseledir, b) bilişsel bir süreçtir ve c) benzerlik dışında başka motivasyonlara sahip olabilir şeklinde açıklanmaktadır. Makalede bu üç konu belagat kitapları ve Kavramsal Metafor Kuramı literatürü açısından karşılaştırmalı olarak incelenmiştir.

Anahtar kelimeler: Kavramsal Metafor Kuramı, metafor, istiare, belagat, dil-düşünce ilişkisi.

\section{Conceptual metaphor theory and rhetoric: A comparative study}

\begin{abstract}
In this study, Conceptual Metaphor Theory, which was first expressed in the literature by Lakoff and Johnson in 1980 with their book Metaphors We Live by. In the book the concepts like source, target, metaphorical linguistic expression, mapping, structural metaphor, ontological metaphor, orientation metaphors, motivation, embodied realism, perceived structural similarity, correlation in experience and primary scene are explained, and the principles of contemporary metaphor theory are compared with what is said about metaphor that corresponds to "istiare" in rhetoric tradition. Ahmed Hamdi Şirvanî (Orak 2013), Ahmed Cevdet Pasha (1323), Recaizade Mahmud Ekrem (1299), Tahir Olgun (1936), Walter Andrews (1976), Yekta Saraç (2015) and Doğan Aksan (1978) define metaphor as a) a matter of language, b) it is a rhetorical tool, c) it is based on similarity. However, according to Conceptual Metaphor Theory, metaphor; a) is a matter of thought, b) is a cognitive process, and c)
\end{abstract}

1 Doç. Dr., İstanbul Üniversitesi, Edebiyat Fakültesi, Türk Dili ve Edebiyatı Bölümü (İstanbul, Türkiye), acicekler@istanbul.edu.tr, ORCID ID: 00oo-0003-0879-1049 [Makale kaylt tarihi: 10.06.2019-kabul tarihi: 19.09.2019; DOI: $10.29000 /$ rumelide.616880]

2 İstanbul Üniversitesi, Türkiyat Araştırmaları Enstitüsü, Türk Dili ve Edebiyatı ABD, Türk Dili BD Doktora Öğrencisi, İstanbul Teknik Üniversitesi, Türk Dili Okutmanı (İstanbul, Türkiye), timurayd@gmail.com, ORCID ID: oooo-o0o31590-9914. 
may have other motivations other than similarity. In this article, these three subjects are examined comparatively in terms of classical rhetoric books and Conceptual Metaphor Theory literature.

Keywords: Conceptual metaphor theory, metaphor, figure, rhetoric, language-thought.

\section{Kavramsal metafor kuramının ana hatları}

Kavramsal Metafor Kuramı, George Lakoff ve Mark Johnson'in 1980 yılında yayımlanan Metaphors We Live by adlı eserinde ilk kez dile getirilmiştir. Bu tarihten itibaren Kavramsal Metafor Kuramı literatürünün George Lakoff, Zoltán Kövecses, Mark Johnson, Mark Turner ve Joseph Grady gibi isimlerin çalışmalarıyla zenginleştiğini görmekteyiz. Akşehirli, Kavramsal Metafor Kuramının metaforun modern/çağdaş anlamda incelenmesi olduğunu ve bu kurama göre metafor kavramının disiplinlinler arası uygulamalarla biliş/zihin(cognition) ve bildirişim (communication) çalışmalarının merkezine yerleştirildiğini belirtmektedir (Akşehirli 2005: 1.). Bu açılamaya göre metafor bir düşünce figürü olarak görülmektedir. Yani Kavramsal Metafor Kuramı'na göre metafor; bir kavram veya deneyim alanını diğer bir kavram veya deneyim alanıyla anlamamızı sağlayan bir bilişsel mekanizmadır. Alan yazınına bakıldığında metaforlar A B'dir şeklinde ve metaforik dilsel ifadeler ile kavramsal metaforu birbirinden ayırt etmek için büyük harflerle gösterilmektedir (Lakoff 1993: 209). A ve B kavram alanlarını açıklarken B, kendisiyle A'nın anlaşıldığı kaynak alandır. A ise B ile anlaşılan hedef alandır. Genellikle daha somut ve belirli bir yapıya sahip olan kaynak alan vasitasıyla, daha soyut ve muğlak bir yapıya sahip olan hedef alan anlaşılmaktadır (Kövecses 2010: 4.). Bu durumu örneklendirmek için HAYAT hedef alanının, YOLCULUK kaynak alanıyla anlaşıldığı HAYAT YOLCULUKTUR 3 metaforu kullanılabilir. Türkçede bu metaforla ilgili pek çok dilsel ifade olmakla beraber burada örneklendirebileceklerimiz şunlardır:

Hayatı boyunca kardeşinin bir adım gerisindeydi.

Bu sorunla ilgili her şeyi geride brraktım.

Hayatta önüme çıan bütün engelleri aştım.

\section{(4)}

Hayatımda bir türlü düzlüğe çıkamadım.

Yukarıda 1-4 arası sıralanmış cümlelerdeki italik yazılan kısımlar incelendiğinde bir adım gerisinde ol, geride bırak-, engelleri aş-, düzlüğe çık- ifadelerinin aslında YOLCULUK kavram alanıyla alakalı olduğu görülmektedir. Bu ifadeler, HAYAT kavram alanının anlaşılması doğrultusunda metaforik

3 Bu metaforun Türkçedeki dilsel ifadeleri Aslıhan Dinçer tarafından detaylı şekilde incelenmiştir. Bkz. DİNÇER, A. (2015), "Metaforların İzinde: HAYAT YOLCULUKTUR", Journal of Turkish Studies, c. 44, ss. 201-214. 
bağlantıyı vermek için kullanılmışlardır. Örneğin 1'deki cümleyi metaforik ifadeden çıkarttığımızda 5 'teki gibi yeni bir cümle ile karşılaşırız:

\section{(5)}

Hayatı boyunca kardeşi ondan daha başarılı oldu.

Görüldüğü üzere 1 ve 5 'teki cümleler aynı anlamı ifade etmekle birlikte 1'de yolculuk kavram alanının dilsel ifadeleriyle bir metaforik bağ kurularak bu durum anlatılmaktadır.

Yukarıda örnekleri verdikten sonra kuramla alakalı alan yazınında, metaforun; a) dille değil düşünceyle ilgili bir mesele olduğu, b) retorik bir araç değil dünyayı anlamlandırmamıza yarayan bir bilişsel süreç olduğu, c) yalnızca benzerlik ilişkisine dayanmadığı gibi pek çok yeni iddia öne sürülmüştür. Bu bakımdan Kavramsal Metafor Kuramı, klasik retorik veya belagat geleneğindeki metafor anlayışından ayrılmaktadır. Sıralanan bu noktalar ise aşağıda detaylı şekilde incelenecektir.

\section{Dil ve düşünce arasında metafor}

Bir toplumun dilinin, onun kültürünü, ruhunu, örfünü, düşünce tarzını yansıttığı muhtelif araştırmacılar tarafından sıkça dile getirilmektedir. Almanların ünlü düşünürü Humboldt dil-toplum ilişkisini "dil, bir ulusun kültür düzeyini gösteren en iyi araçtır. Ancak kendi diline dayanan, kendi dilinde ilerlemeler yapan bir ulus gerçek bir kültürün de yaratıcısı olabilir.” (Akarsu 1998: 7) şeklinde açıklamaktadır. Çünkü dil kendiliğinden olup gelişmiş bir üründen ziyade, toplumsal uzlaşı ile ortaya çıkmış ve gelişmekte olan bir olgudur. Bir toplumda yaşayan kişi kendi toplumunun dünya görüşünden etkilenmektedir. Başka bir yabancı dili çok iyi bilse bile o dilin dünya görüşü içerisine girmesini kendi dilinin dünya görüşünün baskısı engellemektedir (Akarsu 1998: 65). Bireyler içlerinde yoğruldukları dil ile kültürün kodlarıyla yaşar ve düşünce yapıları da yaşadığı toplum içinde inkişaf eden dil ve kültürle gelişir, dolayısıyla dil de toplumla beraber gelişir. Bu konuda Max Müller şu şekilde bir yorum yapmaktadır: "Her dil kendine özgü yerleşik ayrımlar çerçevesine, kendine özgü düşünce biçimlerine sahiptir ve bunlar o dili ana dili olarak öğrenen kişinin gerek zihninin içeriğini ve ürünlerini gerekse edindiği izlenimler yığınını şekillendiren kalıplardır." (Deutscher 2013: 140). Francis Bacon, "halkların ve milletlerin düşünce yapısına ve adabına ilişkin hatırı sayllır miktarda ipucunu onların dillerinde yakalamanın mümkün” olduğunu; Humboldt ise " dil, konuşmalarla şekil kazanır, konuşma da düşünce ve duygunun söze geçmesidir. Bir ulusun dile renk ve karakter kazandıran düşünme ve duyma biçiminin baştan beri dil üzerine etkisi vardır" (Akarsu 1998: 53) diyerek dil-toplum ve doğal olarak kültür bağıntısını açıklamaktadırlar. Farklı milletlerden düşünürlerin yaptı̆̆ı açıklamalardan da açıkça anlaşıldığı üzere bir toplumun kodları kendi diline işlenmiştir. Dil, kaçınılmaz olarak toplumdaki bireylerle ilişkilidir ve sosyal faktörler de dil içinde net bir biçimde yansıtılmıştır. Bir toplum içinde yaşayan bireylerin yaşadıkları bölge, gelir düzeyleri, eğitim seviyeleri, cinsiyetleri bireylerin sosyal faktörlerini belirleyen etkenlerdir. Aşağıdaki göstergebilimsel üçgende düşünce, sembol ve gönderge arasındaki ilişki açıllanmıştır. Buna göre gönderge, dünya gerçekliğini ifade eden bir olay, düşünce veya durum olabilirken düşünce, nesnelerin, olay ve durumların zihnimizdeki gösteriliş biçimidir. Sembol ise, kullanılan dili karşılayan bir olgudur. Çünkü düşüncülerimize bir sembolle, yani konuşmadaki sesler veya yazıdaki harflerle karşı tarafa aktarma ihtiyacı duymaktayız. 


\section{DÜŞÜNCE}

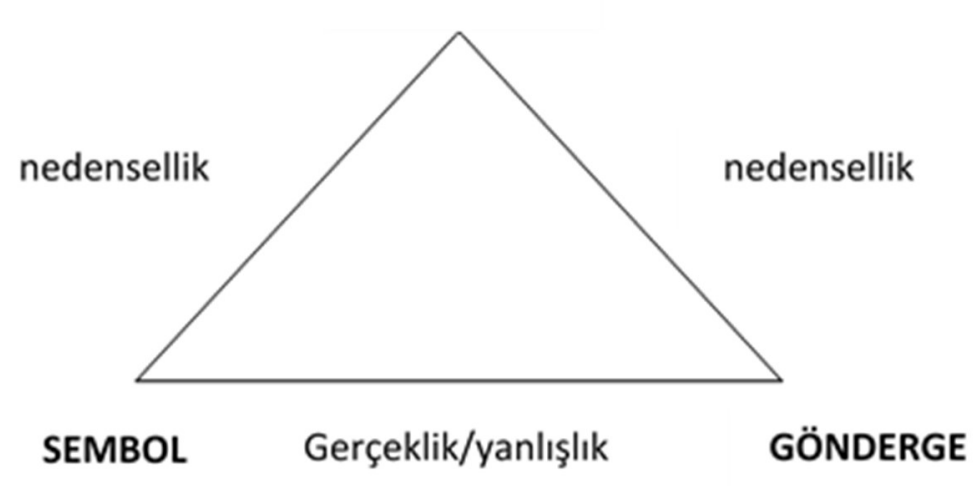

Şekil 1. Göstergebilimsel üçgen

Yukarıda dil ve düşünce arasındaki ilişkiye kısaca yer verilmiştir. Kavramsal metafor kuramı literatüründe de metaforun dil ve düşünceyle ilişkisi önemlidir. Zira bu kurama göre metafor, dil ile alakalı olmayı düşünceye dayanmaktadır. George Lakoff ve Mark Johnson Metaphors We Live by (Lakoff \& Johnson 1980: 3) ve Philosophy in the Flesh'te (Lakoff \& Johnson 1999: 122), Zoltán Kövecses Metaphor - A Practical Introduction'da (Kövecses 2010: IX), Mark Turner Death is the Mother of Beauty'de bu ilkeyi vurgulamaktadır (Turner 2000: 13). Kavramsal Metafor Kuramı literatüründe önemi sıkça dile getirilen bu ilke, Batı düşüncesinde 20. asırda dil - düşünce ilişkisinin sistematik biçimde ele alınmasıyla ilgilidir. Ludwig Wittgenstein "dilimin sınırları dünyamın sınırlarına işaret eder” diyerek bu ilişkiye değinir (Wittgenstein 2002: 68). Wittgenstein'ın bu cümle ile ifade etmek istediği aslında, insanların düşünce sistemlerini dillerinin şekillendirdiği hususudur. Benzer şekilde Martin Heidegger de "dil, varlı̆̆ın evidir" diyerek aynı ilişkiden bahsetmektedir (Heidegger 1993: 217). Benjamin Lee Whorf zihinsel süreçlerin, dillerin kendi geometrik yapılarıyla belirlendiğini söylemekte ve aynı konuya temas etmektedir (Whorf 1956: 257).

Wittgenstein, Heidegger ve Whorf'un söyledikleri göstermektedir ki 20. yüzyılın ilk yarısında Batı düşüncesinin önemli figürleri dil-düşünce ilişkisi meselesine değinmiş; daha çok, dilin düşünce üzerinde etkili olduğu fikrinde ittifak etmişlerdir. Ancak 20. yüzyılın ikinci yarısından sonra yaşanan gelişmeler, bu etkinin tersine dönmesine sebep olmuştur. Steven Pinker, dilin düşünceyi etkilediğine dair bilimsel bir kanıt olmadığını dile getirmektedir (Pinker 2007: 48). Pinker’nn tespitinde, yüzyılın ikinci yarısında önemi artan bilişsel bilim ve nöroloji gibi disiplinlerin yeni bulguları etkili olmuştur. 20. yüzyılın ikinci yarısından sonra ortaya atılan Kavramsal Metafor Kuramı da dil-düşünce ilişkisi üzerine yapılmış geçmiş tartışmalardan etkilenmiş ve düşüncenin dil üzerinde etkili olduğunu vurgulamak adına bir hassasiyet geliştirmiştir. Kavramsal Metafor Kuramı literatüründeki bu hassasiyetle geleneksel belagat literatüründe karşılaşılmaz. Geleneksel anlayışa göre metafor, kelimeler ve kelimelerin dildeki kullanımı ilgili bir meseledir. Kavramsal Metafor Kuramı metaforun dille değil düşünceyle ilgili olduğunu savunurken klasik belagat kitaplarında metafor dille ilgili bir mesele şeklinde ele alınmıştır. Örneğin, Ahmed Hamdi Şirvanînnin Belagat-ı Lisân-ı Osmanî adlı eserinde metafor, lügavî mecaz kavramının altında ele alınmakta ve "manâ-yı asliyyesine teşbih olunan manada alaka-i müşabehetle müstamel lafiz" diye tanımlamaktadır (Orak 2013: 125, 126). Ahmed Cevdet Paşa, Belagat-i Osmaniyye'sinde metaforun "müşabehet alakasıyla karine-i mania ile manâ-yı mevzû-ı ileyhin gayride müstamel olan lafiz" olduğunu belirtmektedir (Ahmet Cevdet Paşa 1323: 133). Recaizade Mahmud Ekrem'in Talim-i Edebiyyat'ına göre “İstiâre demek bir lafzın manâ-yı hakîkîsini nez ile müşâbihi olan 
diğer bir manâ iâre etmek ve tarîf-i diğerle bir şeye -min-cihetin münâsebet ve müşâbeheti olan- şey-i diğerin nâmını âriyyeten vermektir" (Recaizade Mahmud Ekrem 1299: 224). Dönemin belagat kitaplarındaki metafor tanımı, görüldüğü üzere metaforun dil üzerine kurulan, yani lafızla (söz) alakalı bir olgu olduğu şeklinde açıklanmaktadır. Klasik Belagat çalışan araştırmacılar da bu minvalde metafor tanımları yapmaktadırlar. Olgun, metafor için "bir kelimenin manasını muvakkaten diğer bir kelime hakkında kullanmaktır” tanımını vermiştir (Olgun 1936: 54). Andrews metaforun düşünceyle ilgili boyutu olduğunu kabul etmekle birlikte bu boyuta odaklanmanın edebî araştırmaların kapsamı dışında olduğunu söylemektedir (Andrews 1976: 78). Saraç ise "aralarında anlam açısından ilişki bulunan -veya öyle kabul edilen- iki kelime veya cümlenin birini diğeri yerine kullanmaktan oluşan bir dil hadisesidir" şeklinde metaforu açıklamaktadır (Saraç 2015: 119). Geleneksel anlayışın dışında, metaforu anlambilimin kapsamı dahilinde inceleyen araştırmacılardan Aksan da geleneksel anlayışla uyuşan bir metafor tanımı yapmaktadır: "Aralarında uzak yakın ilgi bulunan iki şey arasında bir benzetme yoluyla ilişki kuran, birinin adını ötekine aktaran bir eğilim, bir dil olayıdır (Aksan 1978: 123, 124)”.

Ahmed Cevdet Paşa, Ahmed Hamdi Şirvanî, Recaizade Mahmud Ekrem, Olgun, Andrews, Saraç ve Aksan'ın metafor hakkında söylediklerinde dikkat çeken nokta, metaforun lafizla veya kelimelerle ilgili bir dil hadisesi olduğunu belirtmeleridir. Yalnızca Andrews metaforun düşünceyle ilgili bir boyutu da olduğunu dile getirmiş, ancak bunun edebî araştırmalarda yer almasına gerek olmadığını söylemiştir. Bununla birlikte Kavramsal Metafor Kuramına göre ise metafor klasik anlayışın aksine dille değil düşünceyle alakalı bir kavramdır. Hatta metafor, başlı başına bir bilişsel süreç olarak görülmektedir. Çağdaş metafor anlayışında metaforun dille değil düşünceyle ilgili olması, kuramın kavramsal sıfatıyla vurgulanmasında da görülebilmektedir. Hatta düşüncedeki kavramsal metaforlarla, bunların dilsel ifadelerini birbirinden ayırmak için metaforik dilsel ifade terimi kullanılmaktadır (Lakoff 1993: 209, Kövecses 2010: 4). Metaforik dilsel ifadeler, düşüncedeki kavramsal metaforların yalnızca yansımalarından ibarettir (Lakoff \& Johnson 1999: 122, Kövecses 2010: 7). Mesela 6'daki cümlede görülen yolları ayrıl- birleşik fiili, düşüncedeki AŞK YOLCULUKTUR metaforunun dile yansımış bir metaforik dilsel ifadesidir.

\section{(6)}

Eski eşiyle yolları ayrılah çok oldu.

Lakoff ve Johnson metaforun kelimelerle, yani dille alakalı olmadığını kesinleştirmek için şu önermeyi sunmaktadır: Metafor dille alakalı olsaydı, belirli bir metaforun (mesela AŞK YOLCULUKTUR) her bir dilsel ifadesini ayrı ve birbirinden farklı metaforlar saymak gerekmektedir (Lakof \& Johnson 1999: 122). Lakoff ve Johnson'ın kullandığı önerme AŞK YOLCULUKTUR metaforu ve bu metaforun Türkçedeki metaforik dilsel ifadeleri üzerinden örneklendirilebilir.

Eski eşiyle yolları aymlah çok oldu.

On yılın sonunda ilişkileri çıkmaza girdi. 
Artık ilişkimiz yürümüyor.

(10)

Boşa kürek çekmeye gerek yok, ayrll gitsin!

Kaç yıldır akıntıya karşı yüzdüklerini fark edip anlaşarak ayrıldılar.

Eğer metafor geleneksel anlayışın öne sürdüğü gibi lafızlarla veya kelimelerle ilgili bir dil hadisesi olsaydı; yolları ayrıl-, çıkmaza gir-, (ilişki) yürüme-, (ilişkide) boşa kürek çek-, (ilişkide) akıntıya karşı yüz- metaforik dilsel ifadelerinin hepsinin, farklı kelimelerle kurulduklarından, ayrı ayrı metaforlara işaret ettiğini kabul etmek gerekirdi. Kelimeleri birbiriyle alakalandıran, onların dilsel birer ifade olmaları değil, yolculuk kavram alanına ait düşünsel faaliyetle ilgili olmalarıdır.

Düşüncenin/zihnin bir ürünü olan kavramsal metaforun, zihinde hangi işlemler sonucunda ortaya çıktığını göstermesi bakımından da çă̆daş metafor anlayışı, geleneksel metafor anlayışından ayrılmaktadır. Geleneksel metafor anlayışı, metaforun bilişsel cephesine odaklanmadığı için metaforu ortaya çıkaran zihinsel sürece değinmemektedir. Klasik belagat teorisinin ortaya çıktı̆̆ dönemlerde bilişsel süreçler üzerine herhangi bir çalışma olmadığından bu bilişsel süreçlerin klasik belagat literatüründe olmaması ise gayet doğaldır. Bu makalede her iki dönemdeki metafor kavramı üzerine yapılan araştırmaların ortak ve farklı yönleri verileceğinden bu bilişsel farklılık da vurgulanmıştır.

Klasik Metafor kuramına göre metaforu oluşturan zihinsel süreçte; bir kavram alanının unsurları ile diğer kavram alanının unsurları arasında haritalama gerçekleşir. Haritalama, iki kavram alanındaki unsurların sistematik denklikler oluşturacak şekilde birbiriyle eşlenmesidir. Tıpkı matematikteki fonksiyon işleminde iki kümenin elemanlarının birbirine eşlenmesi gibi metafor da iki kavram alanının unsurlarını birbirine eşler (Lakoff 1993: 206, 207). AŞK YOLCULUKTUR metaforunun haritalaması yukarıdaki 7-11 örnekleri üzerinden şöyle anlatılabilir: 7) Aşk ilişkisinde âşıklar, aynı yolda yürüyen yolcular olarak görülmekte ve aşk ilişkisinin sonlanması yolcuların farklı yollara gitmesiyle eşlenmektedir. 8) Âşılklar/yolcuların yürüdükleri yolun çımaza girmesiyle, ilişkideki sorunların aşılamayacak bir noktaya gelmesi eşlenmektedir. 9) Aşk ilişkisi bir taşıttır. Bu taşıt artık çalışmamakta, dolayısıyla yürümemektedir. 10) Aşk ilişkisi genel olarak bir taşıt, özel olarak teknedir. Âşılklar/yolcular ilişki için çaba sarf etmekte, ancak sarf edilen çaba bir işe yaramamakta, dolayısıyla boşa kürek çekmektedirler. 11) Âşıklar, 10'daki gibi bir deniz yolculuğundadırlar. Ancak bu sefer denizde taşıt olmaksızın hareket eden yüzücülerdir. İlişkideki sorunlar, akıntıyla ve bu sorunları çözmek için harcanan nafile çaba, akıntıya karşı yüzmekle eşlenmiştir. 


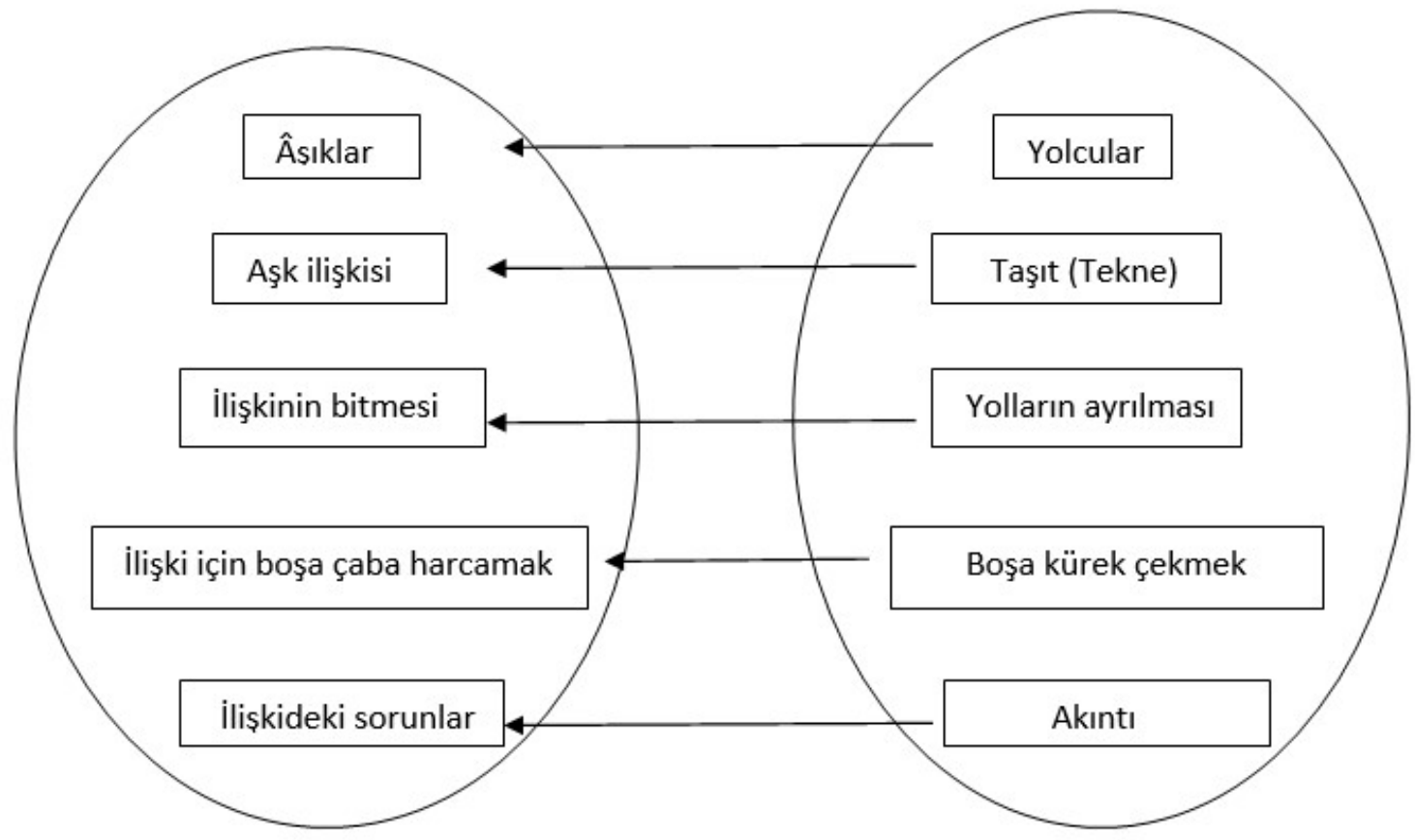

Şekil 2. Metaforik haritalama

\section{Metafor: Retorik bir araç mı, bilişsel bir süreç mi?}

Belagat kitaplarında genel olarak metaforun sözü müzeyyen ve rengin kılmak, beliğane konuşabilmek, üslubu tezyin etmek gibi maksatlarla kullanıldığı belirtilmiştir. Geleneksel anlayışa göre metafor retorik bir araç olup gündelik dilde asıl ifadesini bulmamakta ve bu yüzden edebî metinlerdeki kullanımı esas alınmaktadır. Kavramsal Metafor Kuramına göreyse metafor, retorik bir araç değil, belli kavramları daha iyi anlamamızı sağlayan bilişsel bir süreçtir. Ahmed Hamdi Şirvanî, metaforu kapsayan ilm-i beyan için "tasvîr-i merâm ve beyân-ı efkârda kelâmı müzeyyen ve rengin kılmak için bize mecaz ve istiare ve teşbih ve kinaye tarîklerini bildirecek fen ilm-i beyândır" demiştir (Orak 2013: 115). Ahmed Cevdet Paşa, metaforu "turûk-1 ifâde"den saymakta, doğrudan metaforun retorik bir araç olduğunu söylememektedir. Ancak metaforu da kuşatan belagat için "fasîhane ve belî̆gne ifâde-i merâm edebilmek için 'ilm-i belagât'ı bilmek lazım gelir" demektedir (Ahmed Cevdet Paşa 1323: 6). Recaizade Mahmud Ekrem metaforu "tezyînât-ı üslûb” başlığında incelemiştir (Recaizade Mahmud Ekrem 1299: 216). Andrews'un da metaforu ele alış tarzı onu retorik bir araç olarak gören geleneksel anlayıştan pek farklı değildir (Andrews 1976: 81, 82). Saraç’ın metafora yaklaşımı önceki isimlerden daha farklıdır. Saraç metaforun da dahil olduğu "mecaz" hakkında "Mecazlar dilin bünyesinde tabiî bir şekilde bulunurlar. Hatta günlük dilde mecazları farkına varmadan kullanırız. Bu durumdaki mecazlar dilin o dili kullanan herkesçe paylaşılan ortak malzemesidir.” diyerek Kavramsal Metafor Kuramı anlayışına yaklaşmakta (Saraç 2015: 112), ancak genel olarak edebî metinlerden örnekler vererek Kavramsal Metafor Kuramı anlayışından uzaklaşmaktadır (Saraç 2015: 118-128). Aksan da metaforun "anlatıma güç kazandırmak, etkili olmak amacıyla” kullanıldığını söyleyerek retorik araç görüşüne yakın bir noktada durmuştur (Aksan 1978: 124). Kısmen Saraç ve Aksan haricinde, zikredilen diğer isimlerin ifadeleri, doğrudan metaforla ilgili olmasa da metaforu belagat içerisinde değerlendiren geleneksel anlayışın, konuya nasıl yaklaştığı hakkında bir fikir vermektedir. 
Kavramsal Metafor Kuramı, metaforun insan zihninin evrensel ve doğal bir mekanizması olduğunu öne sürmektedir. Bu mekanizmanın temel işlevlerinden biri ise soyut kavram alanını, somut kavram alanıyla ifade ederek anlaşılır kılmaktır (Lakoff \& Johnson 1980: 115). Mesela aşağıdaki örnek cümlelerde ifadesini bulan ANLAMAK GÖRMEKTİR metaforu, soyut ve sınırları belirsiz ANLAMAK kavram alanını GÖRMEK ile ilişkilendirir ve anlaşılır kılar:

At gözlüklerini çıkar artık.

Konuya farklı bir açıdan bakmayı dene.

Bu gerçeği inkar edecek kadar kör olamazsın.

(15)

Bu konudaki görüşümü değiştirdim.

Türkçede; 12) bir konuda önyargılı olmak at gözlüğü takmakla, 13) bir meseleyi değişik bir düşünceyle anlamaya çalışmak farkh açıdan bakmakla, 14) yine önyargılı olmak veya gerekli anlayıştan yoksun olmak kör olmakla, 15) fikirler, görüş ile haritalanabilir ve böylece ANLAMAK GÖRMEKTİR metaforu ortaya çıkar. Soyut ve muğlak zihinsel bir kavram alanını, somut ve açık olan görsellikle anlamak daha kolaydır.

Dikkatli bakılırsa bu ilkenin metaforun işlevine odaklandığı görülebilir. Geleneksel anlayış metaforu retorik bir araç olarak görürken, Kavramsal Metafor Kuramı metaforu kavramları daha iyi anlamımızı sağlayan bir bilişsel süreç olarak ele almaktadır. Kavramsal Metafor Kuramı literatüründe metaforun anlama işlevine yönelik bu hassasiyet, işlevine göre metaforların tasnif edilmesine yol açmıştır. İşlevlerine göre metaforlar; a) yapısal metaforlar, b) ontolojik metaforlar, c) yönelim metaforları olmak üzere üçe ayrılır. a) Yukarıda metaforik dilsel ifadeleri için örnekler verilen HAYAT YOLCULUKTUR, AŞK YOLCULUKTUR, ANLAMAK GÖRMEKTIR metaforları işlev açısından yapısal metafordur. Yapısal metaforlarda kaynak alan, hedef alan hakkında hayli zengin bir bilgi yapısı sunmaktadır (Lakoff \& Johnson 1980: Kövecses 2010: 37). Yani, hedef alan (HAYAT, AŞK, ANLAMAK) kaynak alanın (YOLCULUK, GÖRMEK) bilgisiyle yapısal olarak çerçevelenmektedir. b) Ontolojik metaforlarda, kaynak alan hedef alan hakkında yapısal metaforlara göre daha az bir bilgi yapısı sunar. Ontolojik metaforların işlevi, soyut kavramlara yeni bir ontolojik statü verilmesidir (Lakoff \& Johnson 1980: 25-31, Kövecses 2010: 38, 39). Mesela "Eline geçen her firsatı kaçırdı" cümlesinde, FIRSAT kavram alanı, ele geçebilecek bir maddeymiş gibi algılanmaktadır. Böylelikle aslında soyut bir kavram olan FIRSAT, MADDE gibi sunularak ona yeni bir ontolojik statü verilmektedir. c) Yönelim metaforlarında kaynak alan, hedef alan hakkında ontolojik metaforlardan da daha az bilgi vermektedir. Yönelim metaforları aşağı - yukarı, ön - arka, iç - dış, merkez - çevre, derin - sığ gibi mekansal kavram çiftlerinden yararlanarak bazı kavramların kavramsal sistemimizde uyumlu hâle getirilmesini sağlar (Lakoff \& Johnson 1980: 14-17, Kövecses 2010: 40). Mesela, aşağı - yukarı ilişkisi dahilinde tepesine 
çık-, üste çık-, küçük düş-, laf altında kal-, tuzağa düş- birleşik fiillerinde KONTROL/GÜÇ SAHİBİ YUKARIDA, KONTROLE/GÜCE MARUZ KALAN AŞAĞIDADIR metaforu mevcuttur4.

Geleneksel anlayış metaforu yalnızca bir retorik araç olarak görürken Kavramsal Metafor Kuramı metaforun anlama, idrâk sürecindeki yerini vurgulamaktadır. Kavramsal Metafor Kuramının anlama, idrâk sürecine odaklanması geleneksel anlayıştan farklı bir tasnife yol açmış, böylelikle geleneksel anlayışla görülemeyecek bazı noktalar gözler önüne serilmiştir.

\section{Metafor ve benzerlik}

Geleneksel anlayışa göre metafor, benzerliğe dayalıdır. Kavramsal Metafor Kuramı literatüründe ise metaforun benzerlik ilişkisi yanında farklı motivasyonları olduğu da belirtilmektedir. Ahmed Hamdi Şirvanî, metaforun benzerlik ilgisine dayalı olduğunu şöyle dile getirir: "İstiâre, manâ-yı asliyyesine teşbîh olunan manâda alâka-i müşâbehetle müstamel lafız olmuş olur ki eğer alâka-i müşâbehet olmaz ise mecâz olur" (Orak 2013: 125, 126). Ahmed Cevdet Paşa, metaforun "müşâbehet alakasıyla karîne-i mânia ile manâ-yı mevzû-ı ileyhin gayride müstamel olan lafız" olduğunu söyleyerek benzerlik ilgisini vurgular (Ahmet Cevdet Paşa 1323: 133). Recaizade Mahmud Ekrem, metaforun aslında benzetme edatı olmayan "kısa bir benzetme" olduğunu söylemekte, buna binaen metaforun belagat geleneğinde "benzetme edatı gizlenmiş benzetme" olarak anıldığını belirtmektedir: "Her bir istiare bir teşbîh-i muhtasardır, fakat edât-ı teşbîhi yoktur. Buna mebnîdir ki istiâreyi 'teşbîh-i muzmerüll-edât' diye de tarif ederler" (Recaizade Mahmud Ekrem 1299: 224). Metaforu bir tür "mecaz" olduğuna dikkat çeken Olgun; bir kelimenin mecaz olması için bir ilgi gerektiğini, bu ilgi benzetme olursa mecaza metafor denileceğini, ilgi benzetmeden başka bir şeyse mecaza "mecâz-ı mürsel” denileceğini söylemektedir: "Bir kelimenin başka bir manada kullanılması, yani hakikatin mecaz olması için bir alaka, yani bir münasebet lazımdır. (...) Alakası teşbih olan mecazlar istiare, başka alakası bulunanlar mecâz-ı mürseldir" (Olgun 1936: 54, 55). Andrews, metafor için benzerlikten başka bir motivasyon göstermemektedir (Andrews 1976: 81, 82). Saraç, metaforun "bir kelimeye aralarındaki benzerlik alakası dolayısıyla lügat/temel anlamının dışında yeni bir anlam vermek” olduğunu söyleyerek benzerlik ilgisini vurgulamıştır (Saraç 2015: 118). Aksan metaforu tanımlarken "aralarında uzak yakın ilgi bulunan iki şey arasında bir benzetme yoluyla ilişki kuran, birinin adını ötekine aktaran bir eğilim, bir dil olayı" ifadesini kullanmakta, benzerlik dışında bir motivasyonun olabileceğine değinmemektedir (Aksan 1978: 124).

Kavramsal Metafor Kuramı literatüründe, benzerlik genellikle metaforun motivasyonlarından yalnızca bir tanesi olarak ele alınmaktadır. Motivasyon ile kast edilen geleneksel anlayıştaki "münasebet"e denk düşmektedir. Geleneksel anlayışta, iki kelime arasındaki münasebet benzerlik ise meydana gelen mecaza metafor, benzerlikten başka bir şeyse mecaz-ı mürsel denmektedir. Kavramsal Metafor Kuramı'nda metaforun movivasyonu; benzerlik olabileceği gibi, deneyimde korelasyon veya kaynak alanın hedef alanın kökeni olması olabilir (Kövecses 2010: 77-86).

Kavramsal Metafor Kuramı'nda benzerlik kavramı bedensel gerçekçilik (embodied realism) felsefesine dayandığı için geleneksel anlayıştaki benzerlikten ayrılmaktadır. Bu felsefeye göre; insan kendi dışındaki cisimleri yalnızca kendi algıladığı kadarıyla bilebilmektedir. Dış dünyanın algısının sınırını insanın bedensel kapasitesi çizdiği için dış dünya, tamamen algıya dayalı şekilde var olmaktadır.

4 Türkçedeki yönelim metaforlarına değinen çalışmalar mevcuttur. Bkz. KEMAL YUNUSOĞLU, M. (2015), "Yönelim Metaforları ve Kültürel Temelleri", Turkish Studies, c. 10/8 Bahar 2015, ss. 1627-1642; SARI, C. (2016), "Deyimlerde Aşağı/Yukarı Yönelim Metaforu”, Uluslar arası Sosyal Arasstırmalar Dergisi, c. 9, s. 44, ss. 212-216; YILDIZLI, M. E. (2017), "Yönelim Metaforlu Deyimlerin Sinıflandırılması", Hitit Ủni. Sosyal Bilimler Enst. Dergisi, c. 10, s. 2, ss. 1489-1498. 
Yani, insan kendi bedeninin fiziki yapısının el verdiği ölçüde dış dünyayı algılamakta ve anlamlandırmaktadır. Dünyayı nasıl algıladığımız ve anlamlandırdığımız ise büyük ölçüde metaforlara dayalıdır (Lakoff \& Johnson 1999: 74-93). Bu yüzden kavramlar arasındaki benzerlik; o kavramların hakikaten kendilerinde bulunan nesnel bir benzerlik değil algıya dayalı yapısal benzerliktir (Kövecses 2010: 81-83). Lakoff ve Johnson, metaforun nesnel bir benzerliğe dayalı olduğunun farz edilmesi hâlinde ortaya bazı çözümsüz sorunların çıkacağını iddia etmiştir. Bunlardan biri benzerliğin simetrik bir kavram olmasıyla ilgilidir. Metafor; nesnel benzerliğe dayalı olsaydı, mesela AŞK YOLCULUKTUR metaforunda kaynak ve hedef alanın yer değiştirebilmesi gerekirdi. Çünkü benzerlik simetrik olduğu için AŞK, YOLCULUK’a benziyorsa, YOLCULUK da AŞK’a benzemelidir. Yani metafor YOLCULUK AŞKTIR şeklinde de tersten ifade edilebilmelidir. Ancak AŞK YOLCULUKTUR metaforuna ait yürüme- (İlişkimiz yürümüyor), çıkmaza gir- (İlişkimiz çıkmaza girdi) dilsel ifadelerini kullanmak doğalken, YOLCULUK AŞKTIR metaforuna ait dilsel ifade mevcut değildir (Lakoff \& Johnson 1999: 125).

Geleneksel anlayışın üzerinde hiç durmadığı bir nokta, metaforun deneyimde korelasyona dayanabileceğidir. "Deneyimde korelasyon" ile ne kast edildiği FAZLA YUKARI, AZ AŞAĞIDADIR metaforuna bakılarak anlaşılabilir:

Sebze fiyatları günden güne yükseliyor.

Enflasyondaki düşüş son zamanlarda daha da belirginleşti.

Yaralı sayısı 18'e yükseldi.

Sesini yükseltme!

FAZLALIK-AZLIK kavram alanının kendi kelime kadrosunu art- ve azal- fiilleri oluşturur. Ancak AŞAĞILIK-YUKARILIK kavram alanına ait yüksel-, düş- fiilleri FAZLALIK-AZLIK söz konusu olduğunda kullanılmakta, böylece FAZLA YUKARI, AZ AŞAĞIDADIR metaforu dilde ifadesini bulmaktadır. Bu metaforun motivasyonu "bir yığına yahut bir kaba madde eklendiğinde seviyenin yükselmesi, yığından yahut kaptan madde çıkarıldığında seviyenin düşmesidir" (Lakoff \& Johnson 1980: 16). İlgili metaforun motivasyonu olan bu durum, gündelik hayatımızda sürekli (mesela bir bardağa su koyarken) karşılaştı̆̆ımız bir olgudur (Lakoff 1990: 276, 277). Bu deneyimde kaba, yığına madde eklenmesi ve kabın, yığının seviyesinin yükselmesi art arda gelmekte, dolayısıyla deneyimde korelasyon oluşturmaktadır. Grady, gündelik hayat deneyimlerimizde bu şekilde art arda gelerek korelasyon oluşturan sahnelere ana sahneler demekte, bunların pek çok metaforun motivasyonunu oluşturduğunu söylemektedir (Grady 1999: 84, 85). Dikkatli bakılırsa, bir yığındaki yahut kaptaki seviyenin yükselmesi ile o yığına, kaba madde eklenmesi arasında bir benzerlik olmadığı görülecektir. Burada deneyimde art arda gelme, yani deneyimde korelasyon mevcuttur. Dolaylsiyla geleneksel anlayışın iddia ettiği gibi, metaforun motivasyonu yalnızca benzerlik değildir. 
Metaforun motivasyonunu oluşturan diğer bir unsur, kaynak alanın hedef alanın kökeni olmasıdır. Bu motivasyon türünde; hedef alanı oluşturan kavram/deneyim alanı, tarihsel olarak kaynak alanı oluşturan kavram/deneyim alanından türemiştir. TARTIŞMA SAVAŞTIR metaforunda bu durum görülebilir. İnsanlık tarihinin ilkel çağlarında TARTıŞMA diye bir kavram/deneyim alanı olmayıp bu alan, SAVAŞ’tan türemiştir (Kövecses 2010: 85). TARTIŞMA SAVAŞTIR metaforunun dilsel ifadeleri aşă̆ıdaki örneklerde görülebilir:

Tartışmadan galip çıktı.

Hâlâ aynı iddiayı savunuyor.

Tartışmayı kaybetti.

Tartışmadan mağlup ayrıldı.

Örneklerde SAVAŞ kavram alanına ait dilsel ifadeler TARTIŞMA kavram alanına aktarılmakta ve metafor dilde ifadesini bulmaktadır.

Geleneksel metafor anlayışı metaforun motivasyonu için yalnızca benzerlik ilgisini göstermiş, Kavramsal Metafor Kuramı benzerlik haricinde deneyimde korelasyon ve kaynak alanin hedef alanm kökeni olması gibi yeni motivasyon türlerini ortaya çıkarmıştır. Ayrıca geleneksel anlayış ile Kavramsal Metafor Kuramı benzerlik ilgisinde de bire bir örtüşmemektedir. Kavramsal Metafor Kuramı, bedensel gerçekçilik denilen felsefi bir temele dayandığı için bu felsefi temelin etkisiyle benzerlik ilgisi yeniden yorumlanmış ve tartışılmış, benzerlik üzerine geleneksel anlayışla ulaşılamayacak yeni görüşler geliştirilmiştir.

\section{Sonuç}

1. Belagat geleneğine göre metafor, aralarında anlam açısından ilişki bulunan iki kelime veya cümlenin birbiri yerine kullanılmasıyla gerçekleşen bir dil hadisesidir. Halbuki Kavramsal Metafor Kuramı literatürüne göre metafor, dille değil düşünceyle ilgili bir süreçtir. Metafor, dille ilgili bir hadise olsaydı AŞK YOLCULUKTUR metaforunu oluşturan yolları ayrll-, çıkmaza gir-, (ilişki) yürüme-, (ilişkide) boşa kürek çek-, (ilişkide) akıntıya karşı yüz- ifadelerinin her birini, -bunların hepsi ayrı ayrı kelimelerden oluştuğu için- farklı metaforlar saymak gerekirdi. Ancak belli bir kavram alanı etrafında kümelenen bu ifadeleri farklı metaforlar saymak, onların ilgili kavram alanına aidiyetini inkâr etmek demek olacağından bu durum mümkün değildir. O hâlde metaforu düşünceyle ilgili bir mesele sayıp bahis konusu ifadeleri metaforik dilsel ifade olarak tanımlamak daha makul görünmektedir. Metaforik dilsel ifadeler, düşüncedeki metaforların dile yansımış ikincil şekillerinden başka bir şey değildir. Düşüncedeki metafor birincil, dildeki ifadeler ikincildir. Belagat kitaplarının metaforun 
düşünceyle ilgili cephesine değinmemesi, 20. yüzyll Batı düşüncesindeki sistematik dil-düşünce ilişkisi tartışmasına yabancı olmalarından kaynaklanmaktadır.

2. Belagat kitaplarında metaforun, doğrudan olmasa da dolaylı şekilde retorik bir araç olarak değerlendirildiği görülmektedir. Belagat geleneğine göre metaforun amacı, sözü müzeyyen ve rengin kılmaktır. Kavramsal Metafor Kuramı literatüründe, metaforun sözü süslemek amacıyla kullanılan retorik bir araç olduğu fikri reddedilmekte, metaforun insan zihninin evrensel ve doğal bir mekanizması olduğu öne sürülmektedir. Bu mekanizmanın temel işlevlerinden biri ise soyut kavram alanını, somut kavram alanıyla ifade ederek anlaşılır kılmaktır. Çağdaş anlayış, bu fikri temel alarak metaforu bilişsel işlevine göre yapısal metaforlar, ontolojik metaforlar ve yönelim metaforları olmak üzere üçe ayırmaktadır. Yapısal metaforlarda kaynak alan, hedef alan hakkında hayli zengin bir bilgi yapısı sunmaktadır. Ontolojik metaforların işlevi, soyut kavramlara yeni bir ontolojik statü verilmesidir. Yönelim metaforları aşağı - yukarı, ön - arka, iç - dış, merkez - çevre, derin - sığ gibi mekânsal kavram çiftlerinden yararlanarak bazı kavramların kavramsal sistemimizde uyumlu hâle getirilmesini sağlar. Bu tasnif, metaforun geleneksel anlayışla görülemeyecek bazı noktalarını gözler önüne sermektedir.

3. Belagat geleneğinde metaforun yalnızca benzerlik ilgisine dayandığı söylenmiştir. Çağdaş anlayışa göre metafor, benzerlik ilgisine dayanabileceği gibi bundan farklı motivasyonları da olabilir. Her ne kadar belagat geleneği ve Kavramsal Metafor Kuramı metaforun benzerliğe dayanabileceği noktasında uzlaşmaktaysa da çağdaş metafor anlayışı bedensel gerçekçilik felsefesini temel aldığı için birbirlerinden ayrılmaktadırlar. Bu felsefeye göre; insan kendi dışındaki cisimleri yalnızca kendi algıladığı kadarıyla bilebilmekte, dış dünya tamamen algıya dayalı şekilde var olmakta ve dış dünyanın algısının sınırını ise insanın bedensel kapasitesi çizmektedir. Bu yüzden kavramlar arasındaki benzerlik; o kavramların hakikaten kendilerinde bulunan nesnel bir benzerlik değil algıya dayalı yapısal benzerliktir. Kavramsal Metafor Kuramı'nın metaforun değiş̧ik motivasyonları arasında gösterdiği diğer iki husus; deneyimde korelasyon ve kaynak alanın, hedef alanın kökeni olmasıdır. Gündelik hayat deneyimimizde art arda gelip deneyimde korelasyon oluşturarak pek çok metaforun motivasyonunu yaratan ana sahneler mevcuttur. Kaynak alanın hedef alanın kökeni olmasına dayanan motivasyon türünde ise; hedef alanı oluşturan kavram/deneyim alanı, tarihsel olarak kaynak alanı oluşturan kavram/deneyim alanından türemiştir.

\section{Kaynakça}

Ahmed Cevdet Paşa (1323), Belagat-ı Osmaniyye, İstanbul: Şirket-i Mürettibiyye Maatbaası.

Akarsu, B. (1998), Wilhelm Von Humboldt'da Dil-Kültür Bağlantısı, İstanbul: İnkılap Kitabevi.

Aksan, D. (1978), Anlambilimi ve Türk Anlambilimi, Ankara: Erol Ofset Matbaacıllk.

Akşehirli, S. (2005), "Çăgdas, Metafor Teorisi”, http://www.ege- edebiyat.org/modules. php?name=Downloads\&d_op=getit\&lid=111. 10.02.2019.

Andrews W. G. (1976), An Introduction to Ottoman Poetry, Minneapolis: Bibliotheca Islamica.

Deutscher, G. (2013), Dilin Aynasında, Çev: Cemal Yardımcı, İstanbul: Metis Yayınları.

Grady, J. E. (1999), "A Typology of Motivation for Conceptual Metaphor: Correlation vs. Resemblance", Metaphor in Cognitive Linguistics içinde, eds. Raymond Gibbs \& Gerard Steen, ss. 79-100, Amsterdam/Philadelphia: John Benjamins Publishing Company

Heidegger, M. (1993), Basic Writings, ed. David Farrell Krell, New York: HarperCollins Publishers.

Kövecses, Z. (2010), Metaphor - A Practical Introduction, New York: Oxford University Press. 
Lakoff, G. (1990), Women, Fire, and Dangerous Things: What Categories Reveal about the Mind, Chicago and London: University of Chicago Press.

Lakoff, G. (1993), "Contemporary Theory of Metaphor", Metaphor and Thought içinde, ed. Andrew Ortony, ss. 202-252, Cambridge: Cambridge University Press.

Lakoff, G. \& Johnson, M. (1980), Metaphors We Live by, Chicago: Chicago University Press.

Lakoff, G. \& Johnson, M. (1999), Philosophy in the Flesh: The Embodied Mind and Its Challenge to Western Thought, New York: Basic Books.

Orak Yllmaz, K. (2013), Belâgat Geleneğimiz ve Belâgat-i Lisân-ı Osmânî, İstanbul: Kitabevi.

Olgun, T. (1936), Edebiyat Lügati, İstanbul: Âsâr-ı İlmiye Kütüphanesi Neşriyatı.

Recaizade Mahmud Ekrem (1299), Talim-i Edebiyyat, İstanbul: Mihran Matbaası.

Pinker, S. (2007), The Language Instinct, New York: HarperCollins Publishers.

Saraç, M. A. Y. (2015), Klâsik Edebiyat Bilgisi: Belâgat, İstanbul: Gökkubbe Yayınları.

Turner, M. (2000), Death is the Mother of Beauty: Mind, Metaphor, Criticism, Christchurch: Cybereditions.

Whorf, B. L. (1956), Language, Thought and Reality, ed. John B. Carroll, Cambridge and Massachusetts: The MIT Press.

Wittgenstein, L. (2002), Tractatus Logico-Philosophicus, trans. D. F. Pears \& B. F. McGuinness, London and New York: Routledge. 